MarKETING AND BRANDING
RESEARCH $\begin{gathered}\text { INDUSTRIAL } \\ \text { MANAGEMENT } \\ \text { INSTITUTE }\end{gathered}$

\title{
Investigating the impact of key dimensions of service quality on customers' satisfaction and loyalty: Evidences from the restaurant industry in Sudan
}

\author{
Dalia M. E. Diab ${ }^{1 *}$, Hesham E. Mohammed ${ }^{2}$, Elham Hassam Mansour ${ }^{3}$, Osman Saad ${ }^{4}$ \\ ${ }^{1,3,4}$ University of Khartoum \\ ${ }^{2}$ Ahmed bin Mohamed Military College, Doha
}

\begin{abstract}
Keywords: Dineserv Model, Customer Satisfaction, Customer Loyalty

Correspondence: daliadlm410@yahoo.com

This paper reports a study that identified the underlying key dimensions of service quality and its impact on consumers' satisfaction and loyalty within the restaurant context in Sudan using Dineserv model. The study is quantitative and descriptive in nature. Data was collected through self-administered questionnaires from 4 restaurants in Sudan. Based on the analyses, four factors including assurance, empathy, tangibility, and reliability were the most significant dimensions of service quality that had positive influence on customer satisfaction while assurance, empathy, and tangibility were the most significant dimensions that had positive influence on customers' loyalty. The results also confirmed the links between service quality dimensions, satisfaction, and loyalty, respectively. The findings of study could be employed by the restaurant managers to improve their marketing strategies.
\end{abstract}

(C)AIMI Journals

\section{Introduction}

For services organizations to be strong and competitive, they have to render high quality services to their customers. The restaurant industry in Sudan has witnessed increased competition and customers demand for high service quality. The food and beverage industry has undergone tremendous development as a result of the marked rise in the standards of living of a large segment of the population worldwide. The consumers have begun to pay attention to the context in which they receive or consume the products, and the food service is not an exemption. Today's consumers demand food and beverage to be delivered to them in a way that will bring them spiritual pleasure and fulfilling experiences. This spiritual pleasure 
can be fulfilled by availing food service with international flavors like Italian, Japanese or Mexican as an example and/or accompanying delivery of food service with music, games, and sport as themes which bring to customers various experiences. What distinguishes theme restaurant from other type of food providers is that in theme restaurants customers must participate in the consuming process directly and chat with service providers face to face. Customers usually pay attention to the style in which the food is presented to them in the service process. They also value any experience that satisfies their own psychological demand and personal preference during the delivery of the food service. So, the management and controlling of the moments of interaction between customers and service providers become the new focus of promoting theme restaurants' service quality. Service quality is becoming a sort of interactive quality; hence, any effort to attract customers and gain sustainable competitive advantage must maintain an interactive service quality to ensure customers to acquire active service experience.

\section{Service Quality}

Service quality has been defined as the delivery of excellent or superior service relative to customer expectation (Zeithaml \& Bitner, 1996). Quality is also defined as fitness for use (Stephens \& Juran, 2004). Both customers and service providers find it very difficult to measure the quality of services because services are intangible products. The other complicating factor in assessing service quality is that services are produced and consumed at the same time. This is the situation which restaurant operators face in measuring the quality of their services (Markovic, Raspor, \& Šegaric, 2010). In case of restaurants, quality is created during the process of service delivery. This fact requires that an instrument to measure service quality must have an effective means of assessing customers' perception of service quality during these service rendering. The provision of the meal and how the meal is provided in a restaurant are two distinct dimensions for service quality (Gronroos 1994). These dimensions give the service quality heterogeneity that hinders the consistency of service delivery and assessment of service quality.

Food is usually perceived as the core element of having a meal in restaurants. The following attributes has been considered as the most commonly used by clients in judging the quality of food in restaurants, these attributes consist of presentation, taste, freshness, and temperature. Presentation is defined as how attractively food is presented as a tangible cue for customer perception of quality (Kivela, Inbakaran, \& Reece, 1999). Food presentation is also seen as on the product factors in the tangible quality scale (Raajpoot, 2002). Taste is also a key aspect in food that influences restaurant customer satisfaction and loyalty (Kivela et al., 1999). Freshness refers to the state of food associated with its crispness, juiciness, and aroma. Temperature is another element of evaluating food quality. Temperature interacts with the three of the major sensory properties, namely taste, smell, and sight which have a strong connection with the critic of food and its associated evaluation (Delwiche, 2004).

Research on service quality has grown in the last three decades. The concept of service quality has emerged as the most important concept pertaining to the marketing of services during this period. Parasuraman, Zeithaml, and Berry (1988) developed a model for measuring service quality called Servqual. The Servqual model has been adopted by 
researchers more than any other instruments, but most of the researchers have criticized the model for its unsuitability for measuring all types of services. The model was also criticized by the original authors for not taking the restaurant industry into consideration. Because of the shortcomings of Servqual, Stevens, Knutson, and Patton, (1995) developed a 29-item scale named Dineserv. The Dineserv model was conceptualized by Stevens et al. (1995) as an instrument to measure service quality in restaurants. Dineserv constitutes the same five dimensions as that of Servqual. Absence of restaurant services is one of its shortcomings of Servqual. Many studies (Kim, Joung, Yuan, Wu, \& Chen, 2009; Kim, McCahon, \& Miller, 2003; Markovic et al., 2010; Vanniarajan, 2009) have used Dineserv model to measure service quality. These studies have come up with new and different factors, as against the Dineserv factors, suggesting the limitation of the Dineserv model.

\section{Customer Satisfaction}

Customer satisfaction has been considered as one of the most important determinants of customer loyalty. It is defined by Cronin and Taylor (1992) as a judgment which is made on the basis of a specific service encounter. Customer satisfaction has been of great interest in services marketing because satisfaction links purchase/consumption to post-purchase phenomena such as attitude change, repeat purchase, positive word-of-mouth, and loyalty (Fornell, Johnson, Anderson, Cha, \& Bryant, 1996; Oliver, 1994; Oliver, 1997). According to Bitner and Hubbert (1994), there are two ways of perceiving customer satisfaction including service-encounter and overall satisfaction. Service-encounter satisfaction happens when customers are satisfied with a specific service encounter while overall satisfaction is an evaluation based on multiple encounters.

Satisfaction is customers' attitudes that occur after comparing the quality of service that they received with their expectations. The level of satisfaction depends on the size of the difference between the experienced satisfaction and the expected one. Thus, satisfaction can be measured by an indicator named service quality level. After comparing the quality of service received with the customer expectation, several situations may arise to establish 3 to 5 point scale for measuring the level of satisfaction.

Service quality plays an essential part in creating customer satisfaction. The connection between service quality and customer satisfaction has been well established in service marketing literature (Antony, Antony, \& Ghosh, 2004; Ladhari 2009). In general, it is commonly argued that a high level of service quality leads to a high level of customer satisfaction. Ladhari (2009), for example, found that customers who receive high level of service quality are likely to be more satisfied with the hotels compared to those who receive low level of service quality.

Many researchers have studied the relationship between service quality and satisfaction (Cronin \& Taylor, 1992; Parasuraman et al., 1988) and the relationship between satisfaction and future intentions of customers (McDougall \& Levesque, 2000). Satisfaction was found to be moderating the quality attitude and purchase intention relationship (Mattila, 2000; Taylor \& Baker, 1994). Consequently satisfaction and perceived service quality should be considered as two separate constructs. 


\section{Customer Loyalty}

Customer loyalty is a core aspect of service rendering because maintaining existing customers is deemed more beneficial for the service provider than trying to attract new ones (Reichheld \& Christine, 2003). Many firms started to consider creating customer loyalty as their major objective, particularly those operating in the service sector (Bove \& Johnson, 2000). Earlier, customer loyalty was measured by act of repurchase. However, several researchers (Dick \& Basu, 1994; Jones \& Sasser, 1995) confirmed that not every customer who repurchases a service is necessarily loyal to the firm. Dick and Basu (1994) categorized loyal customers into four categories based on their attitudes and behaviors. These categories are of varied attributes described as loyalty, latent loyalty, spurious loyalty, and no loyalty. Of the four categories, loyalty and spurious loyalty are linked with high levels of repurchase. The difference between these two groups is that loyalty is associated with a strong positive attitude toward a firm, whilst spurious loyalty is associated with a weak, but positive attitude toward a firm. Moreover, Jones and Sasser (1995) classified the loyalty group into several group including those who are loyal because they want to be in relationship and those who are forced to be in the relationship because they have no exit option. So, it is very important to develop a measure for loyalty that not only care for the tendency of the customer to repurchase, but also such other positive consumer responses such as an intention to spread a positive word-of-mouth communication (Bowen \& Chen, 2001). The interdependence between customer satisfaction and customer loyalty has been confirmed by many studies conducted in several hospitality contexts (e.g., Oh, 2000; Yuksel \& Yuksel, 2002). In restaurants, it has been found that satisfied customers are more loyal to the restaurant than those with less levels of satisfaction. Accordingly, a restaurant clients who are satisfied with the quality of services they received are more likely to revisit and more willing to recommend the restaurant to others (Oh, 2000; Yuksel \& Yuksel, 2002). Operationalizing the concept of satisfaction as overall satisfaction, Taylor and Baker (1994) found that satisfaction is a determinant of customer loyalty.

\section{Survey of Pervious Studies}

Josiam (2014) conducted a study on student run restaurants in USA found that there were six restaurant attributes that generate repeat customers which are food quality, consistency, menu variety, an attractive price-value relationship, ambience, and cleanliness. They believe that the restaurant that focuses on these attributes can raise the level of customer loyalty and retention. In spite of the fact that there is no guarantee that satisfied customers will revisit the restaurant, yet experience proved that 90 per cent of the dissatisfied customers will not revisit the restaurant (Stevens et al., 1995). Chou, Wu, and Huang (2014) suggest that service quality is perceived as the most important factor and managers of restaurants should further understand customer behavior to improve service quality in order to create value and satisfy customers.

Vijayvargy (2014) conducted a study with the aims of identifying the factors of the service quality in restaurant chains and importance level of each of them in making a revisit decision (Customer Loyalty Measurement), using Servqual as a scale for measuring service 
quality. The study reveals three factors including tangibles, convenience, and empathy as the most significant dimensions of service quality amongst the youth of Jaipur, Rajasthan. He stated that superior service quality increases the satisfaction level amongst the customer which in turn results in customer loyalty. Chin and Tsai (2013) attempted to establish a service quality evaluation model for luxurious restaurants in international hotel chains. They argued that reliability is the chief evaluation dimension which followed by empathy. Crucial indicators include maintaining and cleaning the environment and facilities regularly and delivering guaranteed and timely service.

In another study, Vanniarajan and Meharajan (2012) identified important Dineserv factors in the restaurant industry and measuring the impact of various Dineserv variables in each factor on the overall service quality in the restaurant industry. They concluded that confirmatory factor analysis confirmed the existence of six Dineserv factors in restaurant industry namely; relationship benefits, empathy, communication, food quality, price fairness, and tangibles. Moreover, further analyses showed that food quality had the strongest influence on the overall service quality. The authors of this paper have employed a similar version of Dineserv measure for dining quality developed by Stevens et al. (1995), although Vanniarajan and Meharajan (2012) have made reference to the same article, yet the effort of Stevens and his colleagues was not well stated in this paper. The authors of this article went further by giving the same title of Stevens' article to their paper.

Kim et al., (2009) examined the reliability and validity of a modified Dineserv instrument fit specific establishments. The results of this study strongly suggest that the service quality of foodservice operations has a positive impact on customer satisfaction and ultimately contributes to positive word-of mouth recommendations of the establishments. Overall, the results indicated that this instrument can be used in casual dining restaurants to measure the foodservice quality not only in the US, but also in Asian operations. In addition, the positive parameters provide evidence that better quality of products and service yield higher level of customer satisfaction. Polyorat and Sophonsiri (2010) have reached similar conclusions when they examined how each dimension of service quality may exhibit different effects on customer satisfaction and customer loyalty in the chain restaurant context. They surveyed 395 Thai undergraduate students and found that the service quality dimensions of tangibles and empathy have significant influences on customer satisfaction and customer loyalty while the other three dimensions, namely reliabilities, responsiveness, and assurance do not. In addition, customer satisfaction appears to mediate the influence of service quality dimensions on customer loyalty.

Ramseook-Munhurrun (2012) in his study examined the influence of the service quality dimensions on customer satisfaction and behavioral intentions within the restaurant context in an island economy, Mauritius. Factor analysis was performed to determine dimensions that are likely to influence customers' restaurant service evaluations. Based on the analyses, three distinct dimensions were identified by the customers including food quality-reliability, responsiveness-assurance-empathy, and tangibles. Multiple regression analyses were then employed to examine the relative importance of the three service dimensions in determining satisfaction judgments and customers' behavioral intentions. The results support the links between service quality dimensions, satisfaction and behavioral intentions respectively. 
Tripathi and Dave (2014) tried to explore the underlying key dimensions of service quality in restaurants. The study was conducted in New Delhi and its adjoining cities wherein the restaurant customers were surveyed using a structured questionnaire. He used factor analysis to find out the underlying dimensions of service quality. The dimensions he extracted are cultural orientation, aesthetics, ambient settings, empathy, privacy and entertainment, first impression, reliability, and responsiveness. He concluded that the Indian market was contextually different in contrast to various other countries where such research studies have been conducted. He believed that his study provides departure from previous studies and presents greater insight into the service quality factors as perceived by the consumers in India.

However, the results of the above mentioned studies support the strong link between service quality variables, level of customer satisfaction and behavioral intentions, and loyalty. The perception of service quality is likely to vary due to service type and cultural differences. The dining orientation is also expected to vary according to differences in culture.

Kim et al. (2009) recommended the conduct of further research for continuous reexamination of Dineserv model for measuring foodservice quality. This paper is expected to be part of the effort to re-examine Dineserv model as a measure of foodservice quality in Sudan as an Arab context which represent a different cultural milieu. According to the above previous studies, this study is based on the following model:

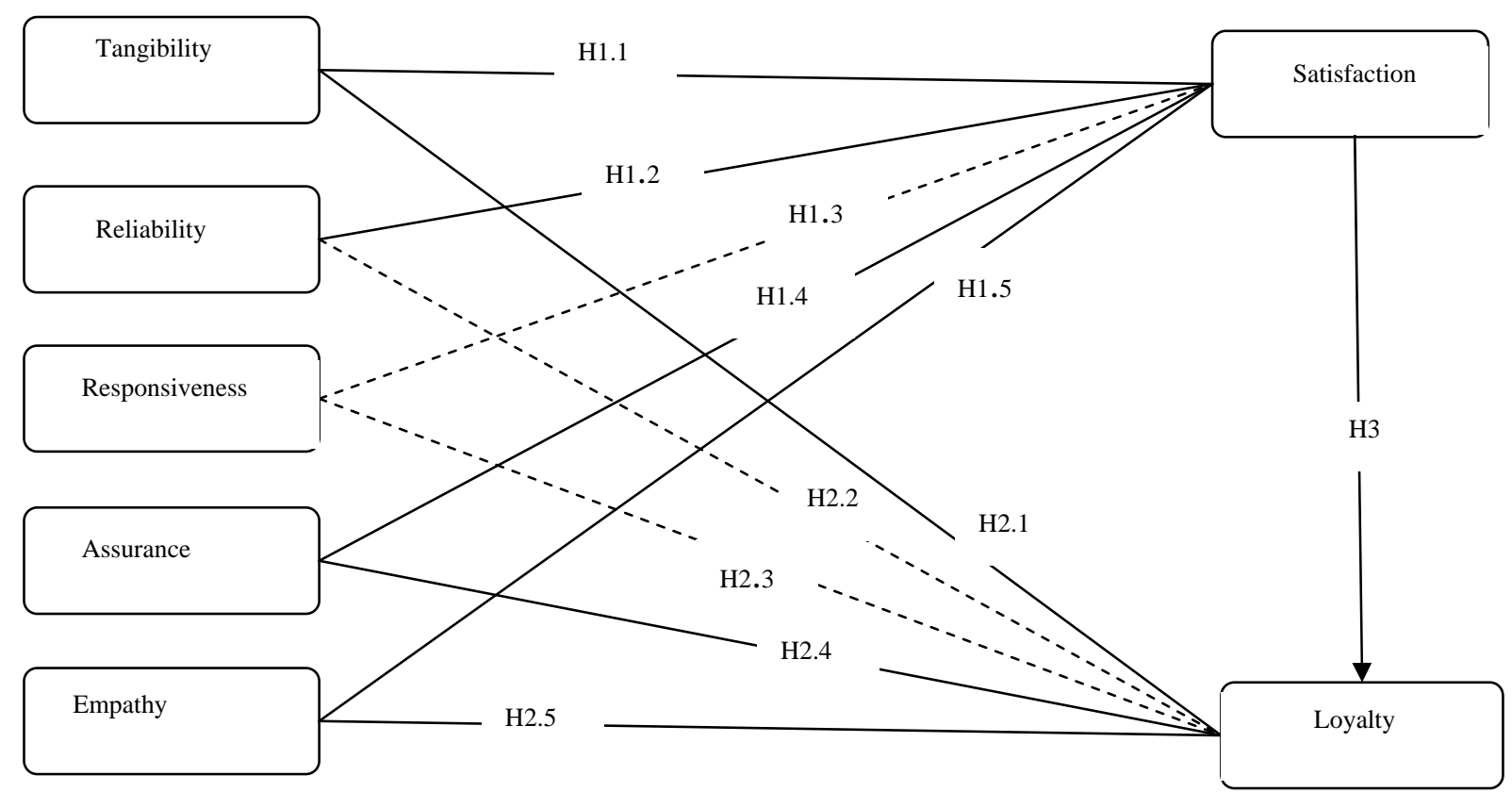

Figure 1. The study model

\section{Method}

\section{Participants}

Four restaurants including Alsaha restaurant $(\mathrm{N}=91)$, Hadaramoot restaurant $(\mathrm{N}=98)$, Laziz restaurant $(\mathrm{N}=98)$, and Pizz Corner restaurant $(\mathrm{N}=100)$ were selected using conveniencesampling method (most accessible). A total of 387 respondents were involved in this survey. Among the respondents ( $\mathrm{N}=387), 221$ (57.1 per cent) were male, and 166 (42.9 per cent) 
were female. The great majority of respondents were aged below 25 (62.3 per cent) but over 25 (37.7 per cent) and 284 (73.4per cent) had a university education. Whereas, 286 (73.9 per cent) were single, while 92 (23.8per cent) of respondents were married and 201 (51.9 per cent) of the respondents were from Khartoum, followed by Bahari 105 (27.1per cent) and Omdurman 81(20.9 per cent). Finally, the largest group was students (57.9 per cent). Table 1 presents details of participants' gender, age, education level, marital status, residency, and occupation.

Table 1

Profile of Respondents

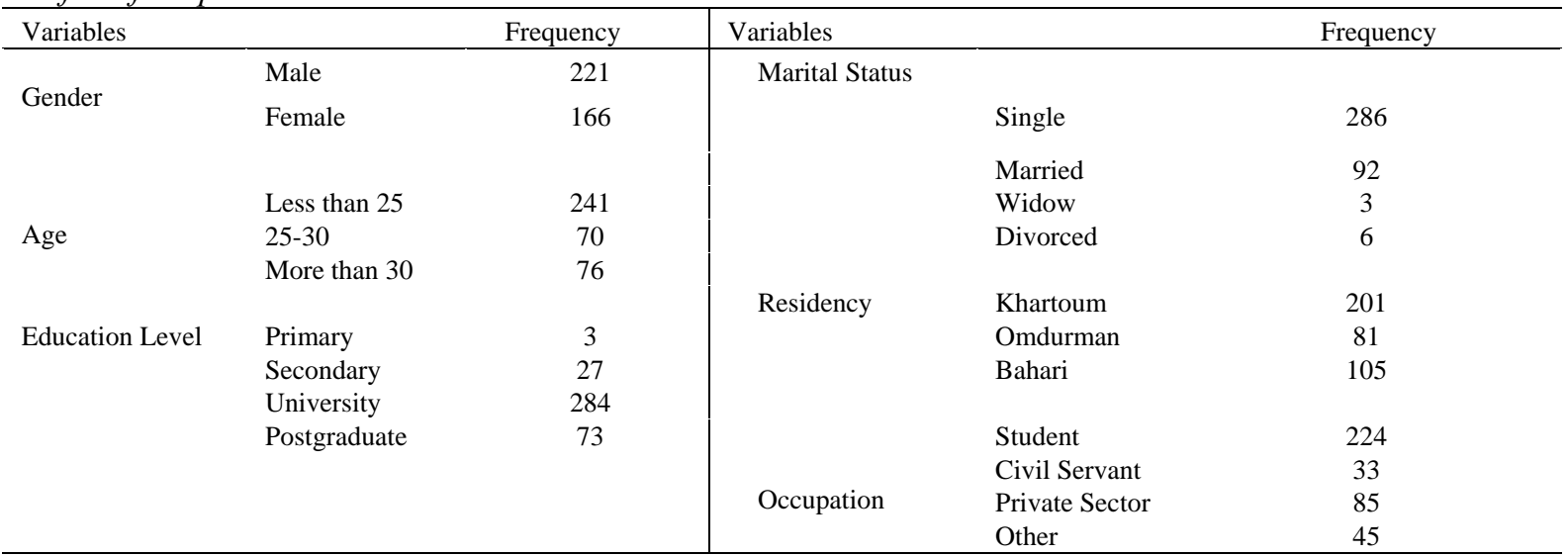

\section{Procedure}

A total of four hundred questionnaires were distributed among restaurants and only three hundred and eighty seven questionnaires were returned from the four restaurant and 13 were dropped due to incomplete answers. Therefore, the response rate of the study is 96.8 per cent. The respondents were given a set of questionnaires which they fill up themselves. The completed questionnaire was returned to the data collectors who waited until the process of responding to the questionnaire by the respondent was completed. The whole process lasted for about 30 to 40 minutes in each restaurant.

\section{Measurement}

Stevens, Knutson, and Patton (1995) suggested 5 dimensions including tangibles, reliability, responsiveness, assurance, and empathy that should be used in measuring service quality of restaurants. These five dimensions called Dineserve. Originally, there were 29 items for these 5 dimensions, of which 10 representing tangibles (includes the physical facilities, equipment, areas and appearance of personnel), 5 representing reliability (includes the correctness of information provided and reliability of the restaurant and service providers), 3 for responsiveness (includes the willingness or readiness of employees to help customers and provide prompt service), 6 for assurance (includes caring, individualized attention) and 5 for empathy (includes knowledge and courtesy of employees and their ability to convey trust and confidence ). Each item was rated on a five-point scale ranging from strongly disagree (1) to strongly agree (5). To measure customer satisfaction and customer loyalty of restaurants' customers, two dimensions were used with 5 items of each. The dimension of customer 
satisfaction included customer decisions, though and experience and the dimension of customer loyalty included word of mouth and purchase intention. These two dimensions were generated from the previous research of Olorunniwo, Hsu, and Udo (2006).

The questionnaire used to collect data from respondents consists of four parts. The first part of the questionnaires contains items that measure the restaurant service quality using a 5point Likert scale ranging from 1 as strongly disagree to 5 as strongly agree. The second part of the questionnaire contains items that measure customer satisfaction with respect to restaurant services quality using a 5-point Likert scale ranging from 1 as strongly disagree to 5 as strongly agree. The third part of the questionnaire measures customer loyalty by asking questions related to their intentions to return and recommend the restaurant to friends and relatives using a 5-point Likert scale ranging from 1 as strongly disagree to 5 as strongly agree. Finally, the last part of the questionnaire contains questions related to the profile of respondents which is considered to be important to gain insights related to their background and characteristics. The collected data was subjected to several statistical analyses such as frequencies and multi-regression, in addition to conducting reliability tests. Descriptive statistics such as frequencies are first performed on the demographic characteristics of respondents

The reliability of the scale was assessed by subjecting the scale measuring service quality, customer satisfaction, and loyalty to a reliability test. The results of the test indicated computed Cronbach's alpha value which was 0.95 . Therefore we can comfortably proceed to further analysis of the data. Multiple regression analyses were employed to explore how the dimensions of service quality were related to the overall customer satisfaction and customer loyalty and to examine the relationship between the combination of service quality dimensions and overall customer satisfaction and between the combination of service quality dimensions and overall customer loyalty. This is a useful technique that can be used to analyze the relationship between a single dependent variable and several independent variables (Hair, Black, Babin, Anderson, \& Tatham, 2006).

\section{Results}

Statistical analyses of the collected questionnaires were computed based on the 387 usable responses obtained from the four restaurants of Alsaha restaurant $(\mathrm{N}=91)$, Hadaramoot restaurant $(\mathrm{N}=98)$, Laziz restaurant $(\mathrm{N}=98)$, and Pizz Corner restaurant $(\mathrm{N}=100)$. The total response rate was 96.8 per cent (387/400). SPSS was used to conduct the following analyses.

\section{Reliability of the Measurements for Each Construct}

The reliability analysis was conducted on seven factors that comprised 43 items. The results showed that Cronbach's alpha coefficients of the seven factors including tangibility, reliability, responsiveness, assurance, empathy, customer satisfaction, and customer loyalty ranged from 0.63 to 0.87 . For the overall variables scale, Cronbach's alpha totals 0.95. These values are well above the generally agreed upon lower limit of 0.60 (Hair et al., 2006), indicating good internal consistency of the factors and high reliability of the scale. 


\section{Hypotheses Testing}

The aim of this study is to identify the key service quality dimensions that affect customer satisfaction and loyalty in restaurant services in Sudan. Therefore, multiple regression analyses were used to determine the relative importance of service quality dimensions in predicting overall customer satisfaction and loyalty.

\section{Impact of Service Quality on Customer Satisfaction}

The value of adjusted $\mathrm{R}^{2}$ shows that customer satisfaction is affected by 63.9 per cent due to tangibility, reliability, responsiveness, assurance, and empathy as a whole and remaining 36.1 per cent is due to other factors that are being held constant in this study but they have their impact on the concept. The value of $F$ statistic shows the overall fitness in model, $F=13.80$.

Multiple regression analysis was used to test the model with five independent variables and customer satisfaction as one dependent variable. The results show that all independent variables positively affect the customer satisfaction.

As Table 2 shows, the results revealed that assurance has much positive impact on customer satisfaction with $\beta=0.31$, empathy has second largest impact with $\beta=0.23$, followed by tangibility and reliability with $\beta=0.21$ and $\beta=0.16$ respectively and responsiveness has weak relationship, $\beta=0.02$.

According to Hypothesis 1, the service quality dimensions had a positive impact on overall customer satisfaction. The coefficients indicated that assurance had the most positive and significant impact on overall customer satisfaction, followed by empathy, tangibility and reliability. Therefore, Hypothesis 1 was supported.

Table 2

The Results of Multiple Regression Analyses for Customer Satisfaction \& Customer Loyalty

\begin{tabular}{|c|c|c|c|c|c|c|}
\hline \multirow[b]{2}{*}{ Variables } & \multicolumn{3}{|c|}{ Model 1} & \multicolumn{3}{|c|}{ Model 2} \\
\hline & $B$ & SEB & $\beta$ & $B$ & $S E B$ & $\beta$ \\
\hline Tangibility & 0.23 & 0.40 & $0.21 * *$ & 0.30 & 0.06 & $0.23^{* *}$ \\
\hline Reliability & 0.15 & 0.46 & $0.16^{* *}$ & 0.08 & 0.06 & 0.07 \\
\hline Responsiveness & 0.23 & 0.37 & 0.02 & 0.04 & 0.05 & 0.04 \\
\hline Assurance & 0.33 & 0.05 & $0.31 * *$ & 0.21 & 0.08 & $0.17 * *$ \\
\hline Empathy & 0.21 & 0.04 & $0.23 * *$ & 0.26 & 0.06 & $0.24^{* *}$ \\
\hline$R$ & 0 & 0.80 & & & 0.65 & \\
\hline$R^{2}$ & & 0.64 & & & 0.43 & \\
\hline Adjusted $R^{2}$ & & 0.64 & & & 0.42 & \\
\hline$F$ for Change in $R^{2}$ & & 13.80 & & & 56.37 & \\
\hline
\end{tabular}

It is evident from Table 2 that the model (service quality dimensions) explains 42.5 per cent of the variance in customer loyalty. The value of F statistic shows the overall Fitness in model. The adjusted $\mathrm{R}^{2}$ of this model is 0.41 , which indicates that about 42 per cent of the variation in customer loyalty was explained by the five dimensions.

From Table 2, only three of the five dimensions (empathy, tangibility, and assurance) significantly and positively influenced loyalty among the restaurant customers. Based on the beta coefficient of each independent variable, it is possible to assess the impact of each variable on the dependent variable, loyalty. According to Table 2, the variable empathy was 
the most important determinant of customers' loyalty; it had the highest standardized coefficient value,

$\beta=0.24$, followed by tangibility with $\beta=0.23$ and assurance with $\beta=0.17$. While, reliability and responsiveness have weak relationship with $\beta=0.07$ and $\beta=0.04$, respectively.

According to second hypothesis, the service quality dimensions had a positive impact on overall customer loyalty. The coefficients indicated that empathy had the most positive and significant impact on overall customer satisfaction, followed by dimension tangibility and assurance.

\section{Impact of Customer Satisfaction on Customer Loyalty}

As presented in Table 3, the adjusted $\mathrm{R}^{2}$ of this model is 0.50 , which indicates that 50.3 per cent of the variation in customer loyalty was explained by the customer satisfaction. According to Table 3 and the third hypothesis, the customer satisfaction had a positive impact on customer loyalty, $\beta=0.70, p<.01$. Therefore, the third hypothsis was supported. This finding suggests that satisfied customers will result in customers dining at the restaurant again in the future and recommending the restaurant to others.

Table 3

The Impact of Customer Satisfaction on Customer Loyalty

\begin{tabular}{lccc} 
& $B$ & $S E B$ & $\beta$ \\
\hline Customer Satisfaction & 0.82 & $0.04^{* *}$ & 0.70 \\
$R$ & & 0.71 & \\
$R^{2}$ & & 0.05 & \\
Adjusted $R^{2}$ & & 0.05 & \\
$F$ for change in $R^{2}$ & 39.06 &
\end{tabular}

\section{Discussion and Conclusion}

The main objective of the current study is to find the interrelationships between service quality, customer satisfaction, and customer loyalty in restaurants sector in Sudan. This study used the Dineserv model to determine the relative importance of each of the service quality factors which influence customer satisfaction and loyalty.

The study results confirm that four variables of the Dineserv model are positively influenced customer satisfaction. In line with previous studies (Lee \& Hing, 1995), the results revealed that among the service quality factors assurance of service quality dimension ranked first as the most important factor influencing customers' satisfaction of the restaurants service quality. Assurance is the knowledge and courtesy of employees and their ability to convey trust and confidence which followed by empathy and tangibility while reliability was the least significant factor and responsiveness factor has no significant influence on customer satisfaction.

There are some differences in this hierarchy according to previous studies (Chin \& Tsai, 2013; Stevens et al., 1995; Vijayvargy, 2014). It seems that restaurants' customers in the sample pay more attention to assurance and empathy variables of their service quality perception. Restaurants' customers want to trust the restaurant and feel that the service provider is competent to supply the service and handle customers in a professional and competent way; they expect to get individual and quality attention from the restaurants staff 
by being considerate towards customers' problem. These attributes of quality are judged to be more important in the minds of the customers, and thus will be the key determinants of customer satisfaction. On the other hand, the results revealed that the service quality dimensions, namely empathy, tangibles, and assurance have significant influences on customer loyalty. This result partially is consistent with the previous findings of Chin and Tsai (2013), Polyorat and Sophonsiri (2010), and Vijayvargy (2014) that empathy, tangibles and assurance dimensions positively influences satisfaction and loyalty while the other dimensions were not. Also, in stimulating customer satisfaction and customer loyalty for the restaurant services suggest that the difference in country or cultural setting could play an important role in determining the relative importance of each dimension of service quality.

Moreover, the results of this study revealed that customer satisfaction has a significant impact on customers' loyalty that is to say satisfied customer will more likely recommend and repurchase the restaurant services. In this highly competitive industry, customer loyalty is a key factor for restaurant sustainability. Since customers have numerous choices in restaurant selection, how to maintain their loyalty and attract more to come are crucial. To satisfy and retain customers and to gain a competitive edge, restaurateurs mangers in Sudanese context should pay attention to assurance, empathy, and tangibles of their restaurants services and continually strive to increase the level of overall service quality of their restaurants which will result in customers' satisfaction and loyalty. This study has confirmed the positive relationship between the service quality attributes, customer satisfaction, and loyalty. Therefore, it is recommended that Dineserv model can be a suitable instrument for measuring the restaurants service quality in the Sudanese context. Therefore, restaurants managers can use this instrument to assess the restaurants service quality. Moreover, the findings of present study could be employed by the restaurant managers to improve their marketing strategies. The study had some limitations that should be considered. The sample size of the study is small and limited to the restaurants customer at selected restaurants in Khartoum city. To be able to generalize the findings for the restaurant sector, a study that would include more restaurants in different geographic locations could be conducted to find out more about service quality, customer satisfaction, and customer loyalty. An attempt to sample noncustomers, who may be different from the convenience sample both behaviorally and demographically, could be conducted to identify barriers to their patronage. Secondly, the study employed dimensions of Dineserv model to assess the service quality and other factors such as food quality, price, perceived value, and waiting time related to the service quality in restaurant service could be considered in future research.

\section{References}

Antony, J., Antony, F. J., \& Ghosh, S. (2004). Evaluating service quality in a UK hotel chain: A case study. International Journal of Contemporary Hospitality Management, 16(6), 380-384.

Bitner, M. J., \& Hubbert, A. R. (1994). Encounter satisfaction versus overall satisfaction versus quality: The customer's voice. In R. T. Rust \& R. L. Oliver (Eds.), Service quality: New directions in theory and practice (72-94).Thousand Oaks, CA: Sage.

Bove, L. L., \& Johnson, L. W. (2000). A customer-service worker relationship model. International Journal of Service Industry Management, 11(5), 491-511. 
Bowen, J. T., \& Chen, S. L. (2001). The relationship between customer loyalty and customer satisfaction. International Journal of Contemporary Hospitality Management, 13(5), 213-217.

Chin, J., \& Tsai, C. (2013). Developing a service quality evaluation model for luxurious restaurants in international hotel chains. Total Quality Management, 24(10), 1160-1173.

Chou, C. K., Wu, P. H., \& Huang, C. Y. (2014). Service climate, service convenience, service quality and behavioral intensions in chain store restaurants. International Journal of Organizational Innovation, 7(1), 161-170.

Cronin, J. J., \& Taylor, S. A. (1992). Measuring service quality: A reexamination and extension. Journal of Marketing, 56(3), 55-68.

Delwiche, J. (2004). The impact of perceptual interactions on perceived flavor. Food Quality \& Preference, 15(2), 137-146.

Dick, A. S., \& Basu, K. (1994). Customer loyalty: Toward an integrated conceptual framework. Journal of the Academy of Marketing Science, 22(2), 99-113.

Fornell, C., Johnson, M. D., Anderson, E. W., Cha, J., \& Bryant, B. E. (1996). The American customer satisfaction index: Nature, purpose, and findings. Journal of Marketing, 60(4), 7-18.

Gronroos, C. (1994). From marketing mix to relationship marketing: Towards a paradigm shift in marketing. Management Decision, 32(2), 4-20.

Hair, J. F., Black, W. C., Babin, B. J., Anderson, R. E., \& Tatham, R. L. (2006). Multivariate data analysis (6th ed.). Upper Saddle River, NJ: Pearson /Prentice Hall.

Jones, T. O., \& Sasser Jr., W. E. (1995). Why satisfied customers defect. Harvard Business Review, 73(6), 88-99.

Josiam, B. M. (2014). Assessing quality of food, service, and customer experience at a restaurant: The case of a student run restaurant in the USA. Journal of Services Research, 14(1), 49-73.

Kim, H. J., McCahon, C., \& Miller, J. (2003). Assessing service quality in Korean casual-dining restaurants using Dineserv. Journal of Foodservice Business Research, 6(1), 67-86.

Kim, H. S., Joung, H.W., Yuan, Y. H. E., Wu, C. K., \& Chen, J. J. (2009). Examination of the reliability and validity of an instrument for measuring service quality of restaurants. Journal of Foodservice, 20(6), 280-286.

Kivela, J., Inbakaran, R., \& Reece, J. (1999). Consumer research in the restaurant environment, part 1: A conceptual model of dining satisfaction and return patronage. International Journal of Contemporary Hospitality Management, 11(5), 205222.

Ladhari, R. (2009). Service quality, emotional satisfaction, and behavioral intentions: A study in the hotel industry. Managing Service Quality, 19(3), 308-331.

Lee, Y. L., \& Hing, N. (1995). Measuring quality y in restaurant operations: An application of the SERVQUAL instrument. International Journal of Hospitality Management, 14(3/4), 293- 310.

Markovic, S., Raspor, S., \& Šegaric, K. (2010). Does restaurant performance meet customers’ expectations? An assessment of restaurant service quality using a modified Dineserv approach. Tourism \& Hospitality Management, 16(2), 181-195.

Mattila, A. (2000). When does mood matter? An examination of two types of hospitality service encounters. Journal of Hospitality \& Leisure Marketing, 7(3), 55-65.

McDougall, G. H., \& Levesque, T. (2000). Customer satisfaction with service: Putting perceived value into the equation. Journal of Services Marketing, 14(5), 392-410.

Oh, H. (2000). Diners' perception of quality, value, and satisfaction: A practical viewpoint. Cornell Hotel \& Restaurant Administration Quarterly, 41(3), 58-66.

Oliver, R. L. (1994). Conceptual issues in the structural analysis of consumption emotion, satisfaction, and quality: Evidence in a service setting. Advances in Consumer Research, 21(1), 16-22.

Oliver, R. L. (1997). Satisfaction: A behavioral perspective on the consumer. New York: McGraw-Hill.

Olorunniwo, F., Hsu, M. K., \& Udo, G. J. (2006). Service quality, customer satisfaction, and behavioral intentions in the service factory. Journal of Services Marketing, 20(1), 59-72.

Parasuraman, A., Zeithaml, V. A., \& Berry, L. L. (1988). SERVQUAL: A multiple-item scale for measuring consumer perceptions of service quality. Journal of Retailing, 64(1), 12-40.

Polyorat, K., \& Sophonsiri, S. (2010). The influence of service quality dimensions on customer satisfaction and customer loyalty in the Chain restaurant context: A Thai case. Journal of Global Business \&Technology, 6(2), 64-79.

Raajpoot, N. A. (2002). TANGSERV: A multiple item scale for measuring tangible quality in the foodservice industry. Journal of Foodservice Business Research, 5(2), 109-127. 
Ramseook-Munhurrun, P. (2012). Perceived service quality in restaurant services: Evidence from Mauritius. International Journal of Management \&Research, 5(3), 1-14.

Reichheld, F., \& Christine, D. (2003). Loyalty: A prescription for cutting costs. Marketing Management, 12(5), 24-25.

Stephens, K. S., \& Juran J. M. (2004). Juran, quality, and a century of improvement: The best on quality. American Society for Quality, Quality Press: Milwaukee.

Stevens, P., Knutson, B., \& Patton, M. (1995). Dineserv: A tool for measuring service quality in restaurants. Cornell Hotel \& Restaurant Administration Quarterly, 36(2), 56-60.

Taylor, S. A., \& Baker, T. L. (1994). An assessment of the relationships between service quality and customer satisfaction in the formation of consumers' purchase intentions. Journal of Retailing, 70(2), 163-178.

Tripathi, G., \& Dave, K. (2014). Exploration of service quality factors in restaurant industry: A study of selected restaurants in New Delhi region. Journal of Services Research, 14(1), 9-26.

Vanniarajan, T. (2009). Dineserv: A tool for measuring service quality in restaurants. Journal of Marketing \& Communication, 4(3), 41-52.

Vanniarajan, T., \& Meharajan, T. (2012). Dineserv: A tool for measuring service quality in restaurants. Journal of Marketing \& Communication, 8(2), 4-11.

Vijayvargy, L. (2014). Measuring service quality using SERVQUAL: A case of restaurant chain. International Journal of Management \& Innovation, 6(2), 60-72.

Yuksel, A., \& Yuksel, F. (2002). Measurement of tourist satisfaction with restaurant services: A segment-based approach. Journal of Vacation Marketing, 9(1), 52-68.

Zeithaml, V. A., \& Bitner, M. J. (1996). Services marketing: Integrating customer focus across the firm (2nd ed.). New York: McGraw Hill/ Irwin. 